\title{
A Study on a Screen Layout for Touch-Screen
}

Takanoshin IMADA, Ki ichi TUKISAKA, Fumiyata KIYOSAWA (TOYO UNIV)

\section{1.はじめに}

本研究は、コンピュータ機器の簡易入力装置 であるタッチスクリーンのレイアウト因子とし て、オブジェクトの表示数、配列方法、大きさ、 配列間隔を取り上げ、それぞれがポイント操作 にどのような影響を及ぼしているのかを人間工 学的に検討し、画面設計に関する指針を得るこ とを目的とした。なお、検討内容に具体性を持 たせるため、オブジェクトのモデルには正方形 のキーを用い、

(1) キーの表示数と配列方法に関する実験

(2) キーサイズとキー間隔に関する実験

の 2 種類の実験によって、キー表示の限界数お よび最適な配列方法と、使いやすいキーサイズ とキー間隔の組合わせを推定した。各実験の被 験者は右利きの男性 (21〜23歳) 20名とした。

\section{2.キーの表示数と配列方法に関する実験}

\section{1 実験方法}

キーサイズは 1 辺 $18.3 \mathrm{~mm}$ とし、表 1 に示す 15種類の配列方法を設定した。実験は、アルフ アベットの表示されているキーの中から数字の キーを見つけ出してポイントするというもので、 この時の反応時間を各配列方法ごとにポイント 時間データとして記録した。

\section{2 実験結果および考察}

タッチスクリーンに複数のキーを表示した場 合、図1に示すようにいずれの配列方法であっ ても、ポイント時間は表示数の増加に伴って長 くなる傾向が見られた。しかし、複数行・列に よる表示には、単一行・列に比べてポイント時 間の増加を抑制する効果があったことから、よ り多くのキーを表示する場合、複数行・列によ る配列が望ましいといえる。
表 1 キーの表示数と配列方法
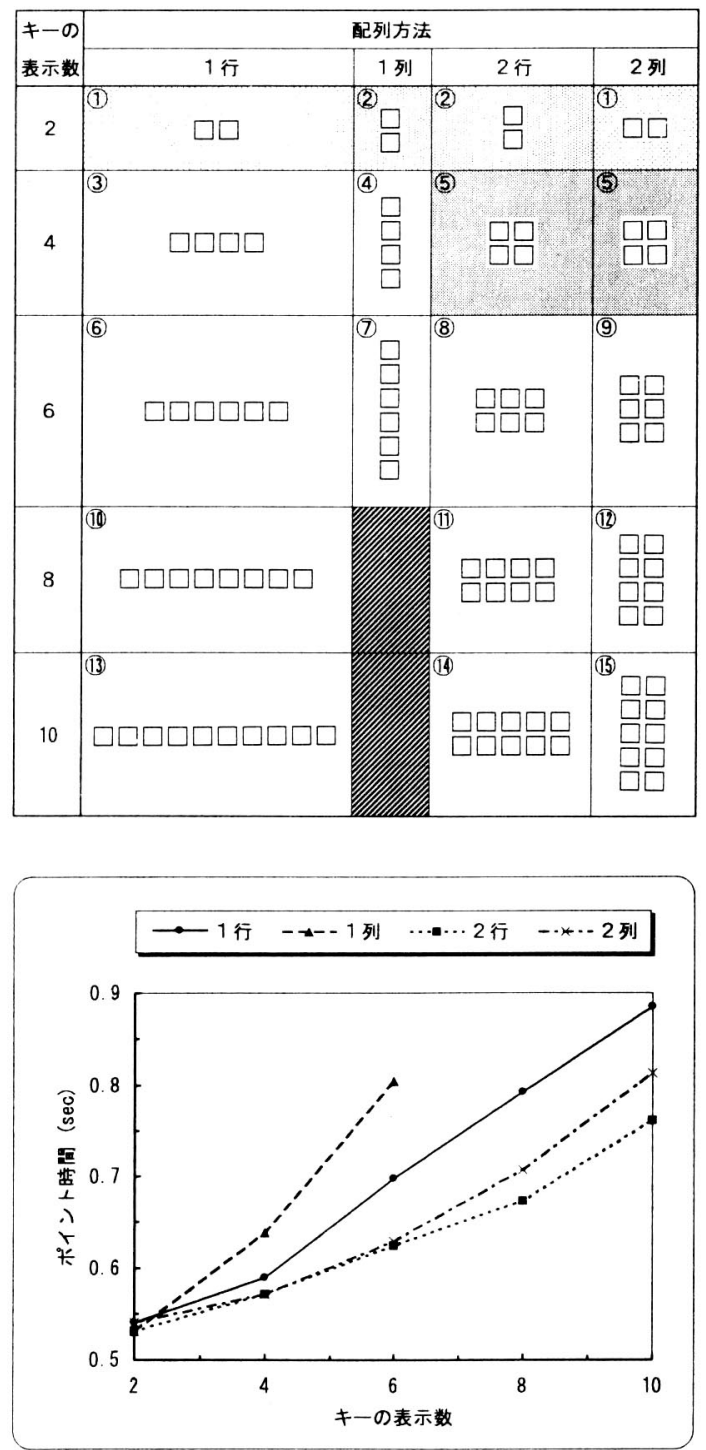

図 1 キーの表示数とポイント時間の関係 


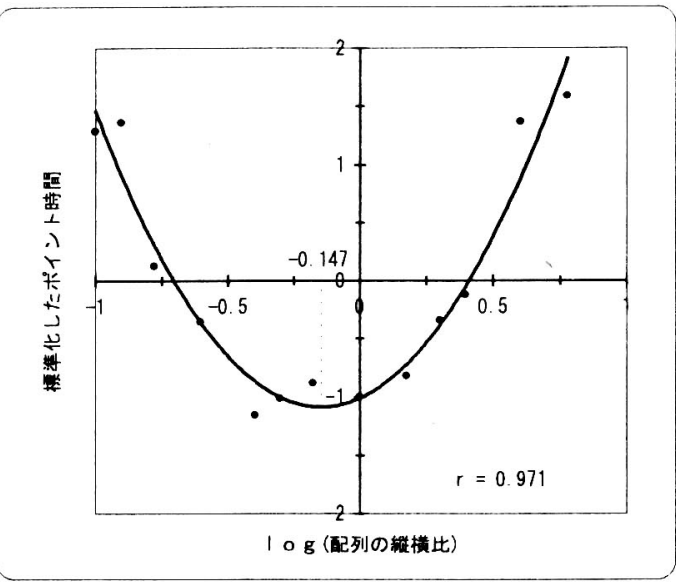

図 2 配列の縦横比とポイント時間の関係

このことは、図 2 に示した配列の縌横比（行 数/列数)の常用対数とポイント時間との関係か ら、配列の集合性が高いほどポイント時間が短 くなることでも分かる(最適縦横比 $=10^{-0.147}$ )。 また、キーの表示数ごとにポイント時間の差を 多重比較した結果、操作性を損なわずに表示可 能なキーの数は、単一行・列では 4 個、複数行 ・列では 6 個であると推定された。これらの指

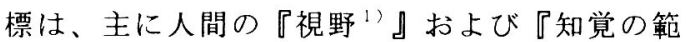
囲 2’』による影響を表すと考えられる。

\section{3.キーサイズとキー閒隔に関する実験}

\section{1 実験方法}

最小キーサイズを 1 辺 $12.8 \mathrm{~mm}$ とて、その面 積が 2.5 倍ずつ大きくなるように 5 種類のキー サイズを設定した。また、隣接するキーの境界 には $0 \mathrm{~mm} 、 17.5 \mathrm{~mm} 、 35.0 \mathrm{~mm} 、 52.5 \mathrm{~mm} 、 70.0 \mathrm{~mm}$ の キー間隔を設け、キーサイズとの全ての組合わ せ (25種類)について実験を行った。画面上には 一度に 2 個のキーを表示し、2.1と同様の方法 で各組合わせにおけるポイント時間データを記 録した。また、ポイント動作終了後には系列力 テゴリー法 ${ }^{3}$ を用いて操作感覚に関する心理テ ストを行った。

\section{2 実験結果および考察}

ここでは、ポイント時間データと操作感覚の 心理尺度を説明変量としたとき、これらの総合 特性である主成分が、キーサイズとキー間隔の 組合わせによる『使いや寸さ』を表すと仮定し て、各組合わせの評価を行った。

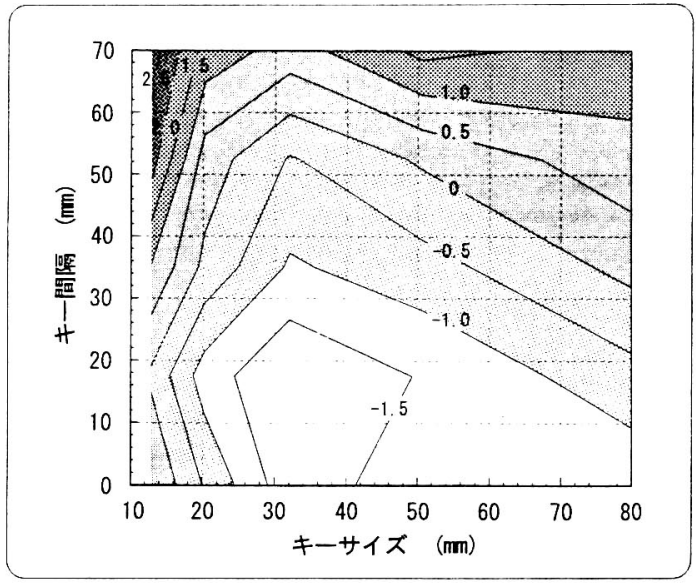

図 3 使いやすさの等值線図

図 3 は、評価結果を使いや寸さ(主成分得点) の等值線図で表したもので、等值線の低くなる キーサイズ30〜 40m 、キー間隔 $10 \sim 20 \mathrm{~mm}$ の範囲 内がポイント操作に最も優れた組合わせである ことが分かる。また、使いやすさはキーサイズ $32 \mathrm{~mm}$ 境に小さすぎても大きすぎても悪化する 傾向があり、その特徽がポイント操作に影響す る人間特性の違いを表していると考えられる。 すなわち、キーサイズが小さいときには『位置 決めの困難度』が、大きいときには『視野』が それぞれ使いやすさに影響を及ぼす主な要因で あると推測される。なお、後者による心理面で の影響は前者に比べ極めて小さかったことから、 キーサイズは最適值よりも大きくすることに対 して許容範囲が広いといえる。

\section{4.まとめ}

以上の結果より、タッチスクリーンの画面設 計を行う際の指針として、

(1)キー配列はできる限り集合性を良くすること (2)操作性を損なわないキ一の表示数は 4 〜 6 個 であること

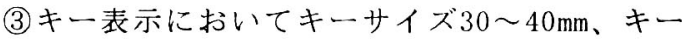
間隔10〜20mmの間が最もポイント操作に優れ た組合わせであること などを人間特性の面から示すことができた。

1)畑田豊彦：日経工外吅入 No. 333,pp. 158-175 (1984) 2)大山正: 別冊艺仗入, pp. 31-41 (1982)

3) 田中良久: 心理学研究法第16卷只度構成, 東京大学出版会

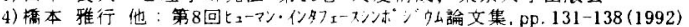

